\title{
Assessment of the influence of selected electrolytic polishing process parameters on the surface roughness of casts made of the CoCrMo alloy
}

\section{0cena wpływu wybranych parametrów polerowania elektrolitycznego na chropowatość powierzchni odlewów ze stopu kobaltowo-chromowo-molibdenowego}

\author{
Małgorzata Ponto-Wolska ${ }^{A-D}$, Leopold Wagner ${ }^{-F}$ \\ Department of Dental Propedeutics and Prophylaxis, Faculty of Medicine and Dentistry, Medical University of Warsaw, Poland \\ A - research concept and design; B - collection and/or assembly of data; $C$ - data analysis and interpretation; \\ $D$ - writing the article; $\mathrm{E}$ - critical revision of the article; $\mathrm{F}$ - final approval of the article
}

Address for correspondence

Małgorzata Ponto-Wolska

E-mail: malgorzata.ponto@gmail.com

\section{Funding sources}

None declared

Conflict of interest

None declared

Received on May 23, 2018

Reviewed on August 13, 2018

Accepted on September 23, 2018

Published online on December 10, 2018

Cite as

Ponto-Wolska M, Wagner L. Assessment of the influence of selected electrolytic polishing process parameters on the surface roughness of casts made of $\mathrm{Co}(\mathrm{rMo}$ alloy. Dent Med Probl. 2018;55(4):395-398. doi:10.17219/dmp/96237

DOI

10.17219/dmp/96237

Copyright

○ 2018 by Wroclaw Medical University

and Polish Dental Society

This is an article distributed under the terms of the

Creative Commons Attribution Non-Commercial License

(http://creativecommons.org/licenses/by-nc-nd/4.0/)

\begin{abstract}
Background. To fabricate some prosthetic restorations, such as metal alloy frameworks for removable partial dentures (RPDs), casting techniques must be used. The penultimate stage of the cast finishing procedure is electropolishing.

Objectives. The aim of the study was to assess the influence of selected electrolytic polishing process parameters on the resulting surface smoothness of the cobalt-chromium-molybdenum (CoCrMo) alloy.

Material and methods. The CoCrMo alloy, 3 experimental and 2 name-brand electrolytes, were used in the study. A total of 25 samples, $63 \mathrm{~mm} \times 10 \mathrm{~mm} \times 1 \mathrm{~mm}$ in size, were cast using the Nautilus ${ }^{\circledR}$ equipment. The cast samples were shaped using metal cutters and carborundum stones and separators, and were sandblasted. The prepared samples were placed in an electrolysis cell as an anode. For each sample, measurements were made by changing the potential of the electrode by $0.2 \mathrm{~V}$ in the range from $1.2 \mathrm{~V}$ to $7.0 \mathrm{~V}$. The surface of the samples was analyzed using a profilometer. An optical microscope and a scanning electron microscope (SEM) were used to examine the structure of the surface.
\end{abstract}

Results. An analysis of the obtained results showed no statistically significant differences between the BEGO Wirolyt ${ }^{\circledR}$ electrolytic polishing liquid (WB) and experimental electrolytes K15, K8 and K13, all of which were significantly better than the Dentaurum Electrolyt ${ }^{\circledR}$ polishing solution (ED). The microscope images indicated differences in the surface structure of the samples; in the SEM images, inclusions were also visible.

Conclusions. The experimental electrolytes did not differ in quality from one of the name-brand electrolytes and were even better than the other one. The obtained surface roughness values (Ra) did not differ significantly from those achieved by other researchers.

Key words: surface roughness, electrolytes, cobalt-chromium-molybdenum alloy, casting technique

Słowa kluczowe: chropowatość powierzchni, elektrolity, stop kobaltowo-chromowo-molibdenowy, technika odlewu 


\section{Introduction}

To fabricate some prosthetic restorations, such as metal alloy frameworks for removable partial dentures (RPDs), casting techniques must be used. The processing of metal alloys involves many physical and chemical phenomena, which may result in difficult to remove defects in the form of excessive roughness and pits, occurring on the surface of the cast. One of the reasons why such defects occur is the mechanical penetration of the liquid metal into the pores in the molding mass. ${ }^{1,2}$

Once punched out of the casting ring, the cast has to undergo mechanical and electrolytic polishing. Mechanical polishing is done with tungsten-carbide grinding discs and corundum stones, followed by sandblasting to remove the residues of the molding mass. ${ }^{3}$ The sandblasting and grinding processes may cause friction and temperature increases, and thus promote disturbances in the internal structure of the alloy, which may give rise to areas of a heterogeneous structure. A common defect is surface deformation, i.e., a thin layer of a deformed crystalline structure and highly refined (disintegrated) grains, which can result in the formation of a local corrosion center and cause corrosion of the alloy. ${ }^{4}$ In the available literature, there are papers about the influence of cast quality on the strength of metal RPD clasps. ${ }^{5-8}$

The next step of the cast finishing procedure is electropolishing. The electrolytic polishing process is carried out in an electrolyte solution, containing sulfuric acid and other substances. ${ }^{9}$ Properly conducted, the electrochemical procedure removes oxides, reduces corrosion, releases metal ions, and enhances the strength of the alloy, but it does not result in a high gloss or optimal smoothness. ${ }^{10,11}$ Adequate electropolishing also makes the final polishing easier to carry out. The final stage of the cast finishing procedure is polishing with a rubber point, polishing paste for alloys, and steam or detergent. According to the aforementioned study by Jang at al., as well as Kuhar and Funduk, after the final stage, the average roughness value ( $\mathrm{Ra}$ ) of $0.2 \mu \mathrm{m}$ or less is clinically satisfactory, as this rugosity will collect only a small amount of plaque.,12 In agreement with this, Bollen et al. define $\mathrm{Ra}=0.2 \mu \mathrm{m}$ as "the threshold Ra", and report a clear reduction in the amount of biofilm deposited below this value. ${ }^{13}$

To obtain the optimal smoothness, good casting quality is required. The lowest possible $\mathrm{Ra}$ values must be achieved by electropolishing and the final machining must be carried out correctly. In dental materials, smooth surfaces result in easy surface cleaning and less microbial accumulation, which means that the surface roughness of the materials is important for the long-term clinical performance of dental restorations. ${ }^{14}$

Due to the shortage of papers evaluating the influence of various electrolytic polishing parameters on the quality of cast surfaces, and the lack of information on the full composition of name-brand electrolytes, the authors decided to develop their own electrolytes and investigate the influence of selected process parameters (temperature, time and current) on the resulting surface smoothness of the cobalt-chromium-molybdenum (CoCrMo) alloy.

\section{Material and methods}

Wironit ${ }^{\circledR}$ Extrahard CoCrMo alloy (BEGO, Bremen, Germany) was chosen for the study. Three experimental electrolytes - K8, K13 and K15 - were formulated, containing, by weight, $8.6 \%, 13.5 \%$ and $15.8 \%$ sulfuric acid, $91 \%, 85.8 \%$ and $83.4 \%$ ethylene glycol, and $0.4 \%, 0.7 \%$ and $0.8 \%$ water, respectively. The 2 name-brand electrolytes selected for use in the study were Electrolyt ${ }^{\circledR}$ (Dentaurum, Ispringen, Germany) (ED) and Wirolyt ${ }^{\circledR}$ (BEGO) (WB). A total of 25 samples, $63 \mathrm{~mm} \times 10 \mathrm{~mm} \times 1 \mathrm{~mm}$ in size, were molded from casting wax and subsequently turned into CoCrMo alloy samples, cast in a Nautilus ${ }^{\circledR}$ casting machine (BEGO), using the lost wax technique.

The samples were shaped using metal cutters and carborundum stones and separators to remove the excess metal and casting channels. Next, they were sandblasted with aluminum oxide and subjected to electrolytic polishing. The electrolyte was then poured into an electrolysis cell and heated to an appropriate temperature. The prepared samples were placed in the electrolysis cell as an anode. Its potential was measured relative to the calomel electrode, which was as close as possible to the anode. Electrolysis was carried out for successive anode potential values. It was found that after about $5 \mathrm{~min}$, the current was stabilized. This value was taken as the electrolysis current. The measurements were performed between the $5^{\text {th }}$ and $15^{\text {th }}$ minute of anodic dissolution, varying the temperature from $25^{\circ} \mathrm{C}$ to $60^{\circ} \mathrm{C}\left(35^{\circ} \mathrm{C}\right.$ for the name-brand electrolytes) and varying the potential of the electrode from $1.2 \mathrm{~V}$ to $7.0 \mathrm{~V}$ in 0.2 -volt steps. The course of the curves indicated the anode potential value above which electrolytic polishing occurred.

In the case of the name-brand electrolytes, a potential of $12 \mathrm{~V}$ and a temperature of $35^{\circ} \mathrm{C}$ were selected on the basis of the obtained potentiostatic curves. Electrolytic polishing was carried out for $12 \mathrm{~min}$. (The electrolyte manufacturers recommend polishing for 5-15 min at a temperature of $20-40^{\circ} \mathrm{C}$ and at a current of $2-2.5 \mathrm{~A}$.)

Once the polishing was completed, each sample was washed with distilled water and then with acetone, and finally dried with compressed air. The surfaces of the samples were analyzed using an Alpha-Step ${ }^{\circledR} 200$ profilometer (KLA-Tencor Corp., Milpitas, USA). The Warsaw University of Technology Nikon ${ }^{\circledR}$ E995 optical microscope (Nikon Corp., Tokyo, Japan) and the Quanta ${ }^{\circledR} 200$ scanning electron microscope (SEM) (FEI Company, Hillsboro, USA) were used to examine the structure of the surfaces. The results obtained were subjected to statistical analysis using STATISTICA v. 13.1 software (StatSoft Inc., Tulsa, USA). Ten pairwise comparisons were done using Student's $t$-test with Bonferroni corrections, so the critical $p$-value was 0.005 . 


\section{Results}

The data from the profilometer are presented in Table 1. The lowest Ra values were obtained for:

- WB: the average value of the current density at $35^{\circ} \mathrm{C}$ amounted to $49.42 \mathrm{~mA} / \mathrm{cm}^{2}$ for the potential range $3.2-3.6 \mathrm{~V}$;

- K15 solution: the average value of the current density at $25^{\circ} \mathrm{C}$ amounted to $17.47 \mathrm{~mA} / \mathrm{cm}^{2}$ for the potential range $2.2-2.7 \mathrm{~V}$, at $40^{\circ} \mathrm{C}$, the average value was $49.81 \mathrm{~mA} / \mathrm{cm}^{2}$ for the potentials $2.6-3.2 \mathrm{~V}$, and at $60^{\circ} \mathrm{C}$, it was $131.97 \mathrm{~mA} / \mathrm{cm}^{2}$ for the potentials 3.1-3.8 V;

- K8 solution: the average value of the current density at $25^{\circ} \mathrm{C}$ amounted to $60.49 \mathrm{~mA} / \mathrm{cm}^{2}$ for the potential range $3.2-4.0 \mathrm{~V}$, at $40^{\circ} \mathrm{C}$, the average value was $99.09 \mathrm{~mA} / \mathrm{cm}^{2}$ for the potentials $3.8-4.4 \mathrm{~V}$, at $60^{\circ} \mathrm{C}$, it was $185.68 \mathrm{~mA} / \mathrm{cm}^{2}$ for the potentials $4.6-5.0 \mathrm{~V}$;

- K13 solution: the average value of the current density at $25^{\circ} \mathrm{C}$ amounted to $34.58 \mathrm{~mA} / \mathrm{cm}^{2}$ for the potential range $2.6-3.4 \mathrm{~V}$, at $40^{\circ} \mathrm{C}$, the average value was $71.78 \mathrm{~mA} / \mathrm{cm}^{2}$ for the potentials $2.8-3.6 \mathrm{~V}$, at $60^{\circ} \mathrm{C}$, it was $154.87 \mathrm{~mA} / \mathrm{cm}^{2}$ for the potentials $3.4-4.2 \mathrm{~V}$;

- ED: the average value of the current density at $35^{\circ} \mathrm{C}$ amounted to $34.23 \mathrm{~mA} / \mathrm{cm}^{2}$ for the potential range $2.8-3.4 \mathrm{~V}$.

The results of the statistical analysis are presented in Table 2.
The obtained microscope images indicated differences in the surface structure of the samples, and in the SEM images inclusions were also visible. Figure 1 shows a SEM image of a sample after electrolytic polishing with WB; there are visible inclusions on the surface.

\section{Discussion}

Current density, time, temperature, and surface size of the object are parameters that determine the rate of electrolysis. ${ }^{6}$ Research conducted under the same conditions

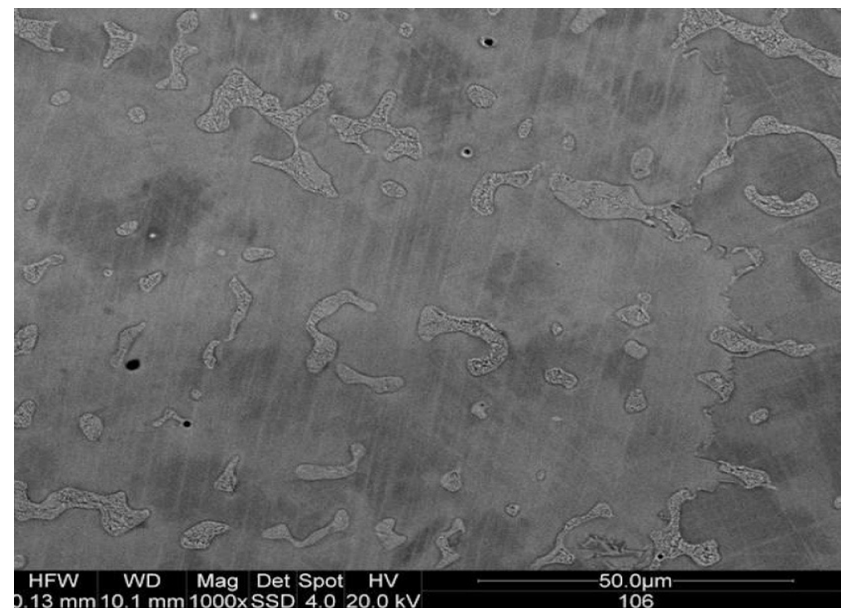

Fig. 1. Sample surface polished with WB

Table 1. Roughness values ( $\mathrm{Ra}$ ) of the tested samples [ $\mu \mathrm{m}]$

\begin{tabular}{|lc|c|c|c|c|c|c|}
\hline Electrolyte & Sample 1 & Sample 2 & Sample 3 & Sample 4 & Sample 5 & Mean & Standard deviation \\
\hline WB & 0.868 & 0.793 & 0.542 & 0.845 & 0.821 & 0.774 & 0.133 \\
ED & 1.255 & 1.321 & 1.184 & 1.413 & 1.229 & 1.280 & 0.089 \\
K8 & 0.926 & 1.020 & 1.032 & 0.905 & 0.842 & 0.945 & 0.080 \\
K13 & 1.014 & 1.018 & 0.911 & 1.172 & 0.908 & 1.005 & 0.108 \\
K15 & 0.808 & 0.816 & 0.826 & 1.008 & 0.912 & 0.874 & 0.086 \\
\hline
\end{tabular}

WB - Wirolyt (BEGO); ED - Electrolyt (Dentaurum); K8, K13, K15 - experimental electrolytes.

Table 2. Student's t-test for comparisons of 10 pairs (the significance level is 0.005 )

\begin{tabular}{|c|c|c|c|c|c|c|c|}
\hline \multirow{2}{*}{$\begin{array}{c}\text { Group } 1 \text { vs } \\
\text { group } 2\end{array}$} & \multicolumn{7}{|c|}{ Samples treated as independent variables } \\
\hline & group 1 average & group 2 average & $t$ & $d f$ & $p$-value & $\begin{array}{c}\text { group } 1 \\
n\end{array}$ & $\begin{array}{c}\text { group } 2 \\
n\end{array}$ \\
\hline WB vs ED* & 0.7738 & 1.2804 & -7.09097 & 8 & 0.000103 & 5 & 5 \\
\hline WB vs K8 & 0.7738 & 0.9450 & -2.47061 & 8 & 0.038674 & 5 & 5 \\
\hline WB vs K13 & 0.7738 & 1.0046 & -3.02205 & 8 & 0.016508 & 5 & 5 \\
\hline WB vs K15 & 0.7738 & 0.8740 & -1.41921 & 8 & 0.193605 & 5 & 5 \\
\hline ED vs K8* & 1.2804 & 0.9450 & 6.25116 & 8 & 0.000245 & 5 & 5 \\
\hline ED vs K13* & 1.2804 & 1.0046 & 4.41084 & 8 & 0.002254 & 5 & 5 \\
\hline ED vs K15* & 1.2804 & 0.8740 & 7.34460 & 8 & 0.000080 & 5 & 5 \\
\hline K8 vs K13 & 0.9450 & 1.0046 & -0.99232 & 8 & 0.350103 & 5 & 5 \\
\hline K8 vs K15 & 0.9450 & 0.8740 & 1.35161 & 8 & 0.213473 & 5 & 5 \\
\hline K13 vs K15 & 1.0046 & 0.8740 & 2.12130 & 8 & 0.066690 & 5 & 5 \\
\hline
\end{tabular}

$t$ - according to Student's $t$-test; $d f$ - degrees of freedom for each comparison ( $d f=$ the number of samples in both groups - the number of groups; $d f=5+5-2=8){ }^{*}$ significant comparisons. 
as the present study have shown that the current density values for the same anode potentials differ depending on the electrolyte temperature and composition. ${ }^{15,16}$ The potential level at which the polishing process begins increases along with the decreases in the sulfuric acid concentration in the electrolyte solution and the increases in the electrolyte temperature. Based on the statistical analysis of the profilometer results, there were no statistically significant differences between electrolytes WB, K15, K8, and K13, all of which were significantly better than ED.

All the obtained images showed heterogeneity and inclusions on the surfaces of all the CoCrMo alloy samples after electrolyte polishing. Numerous studies on $\mathrm{Co}-\mathrm{Cr}$ alloys have revealed that their structure is predominantly characterized by the presence of large grains, which is associated with lower mechanical and physical properties, such as compressive strength, tensile strength and flexibility. ${ }^{17,18}$ An analysis of the alloy microstructure showed that there were smaller grains in the thinner parts and larger grains in the thicker ones. This is due to the faster cooling of the thin parts, which disenables grain growth. ${ }^{17,19}$ Intermetallic precipitations were also observed at the boundary planes of the grains. They form clusters of trace amounts of elements such as $\mathrm{Cr}, \mathrm{Ni}, \mathrm{Mo}$, and $\mathrm{W}$, and can lower the tensile and compressive strength. ${ }^{20,21}$

The results of studies by Taylor et al. and Aydin, obtained using other research methods, were similar to those of the present study. ${ }^{22,23}$ Taylor et al. examined the surface of CoCrMo alloy samples, sandblasted using $\mathrm{Al}_{2} \mathrm{O}_{3}$, and then polished in the Metrodent ${ }^{\circledR}$ electrolyte (Metrodent Ltd., Lowergate Works, Lowergate Paddock, Huddersfield, UK) . The Ra values obtained in the tests amounted to $\approx 1.87 \mu \mathrm{m} .{ }^{22}$ On the other hand, Aydin investigated the surface roughness using a perthometer. The average Ra value he obtained was $1.884 \mu \mathrm{m} .{ }^{23}$

The roughness of a metal surface is an important factor influencing the deposition of biofilm on a denture. ${ }^{20,24}$ Rough surfaces of dental materials near the gingiva make a suitable location for microbial accumulation. Microbes penetrate the recesses and unevenness of the surfaces and are often not sufficiently removed during hygienic procedures; consequently, they become attached to the denture. ${ }^{1}$ Excessive surface roughness is therefore a significant cofactor in the pathogenesis of denture stomatitis. ${ }^{25}$ The surface roughness of a casting after electropolishing is almost 10 times higher than the level considered optimal, so final polishing is required before giving the restoration to the patient.

\section{Conclusions}

The experimental electrolytes did not differ in quality from one of the name-brand electrolytes and were even better than the other one. The obtained surface roughness did not differ significantly from that achieved by other researchers.

\section{References}

1. Torabi K, Farjood E, Hamedani S. Rapid prototyping technologies and their applications in prosthodontics: A review of literature. J Dent. 2015;16:1-9.

2. Jang KS, Youn SJ, Kim YS. Comparison of castability and surface roughness of commercially pure titanium and cobalt-chromium denture frameworks. J Prosthet Dent. 2001;86:93-98.

3. Taga Y, Kawai K, Nokubi T. New method for divesting cobalt-chromium alloy castings: Sandblasting with a mixed abrasive powder. J Prosthet Dent. 2001;85:357-362.

4. de Melo JF, Gjerdet NR, Erichsen ES. Metal release from cobaltchromium partial dentures in the mouth. Acta Odontol Scand. 1983;41:71-74.

5. Kim D, Park C, Yi Y, Cho L. Comparison of cast Ti-Ni alloy clasp retention with conventional removable partial denture clasps. J Prosthet Dent. 2004;91:374-382.

6. Rudd R, Rudd KD. A review of 243 errors possible during the fabrication of a removable partial denture: Part II. J Prosthet Dent. 2001;86:262-276.

7. Vallittu PK, Kokkonen M. Deflection fatigue of cobalt-chromium, titanium, and gold alloy cast denture clasp. J Prosthet Dent. 1995;74:412-419.

8. Henriques GE, Consani S, Rollo JM, Andrade e Silva F. Soldering and remelting influence on fatigue strength of cobalt-chromium alloys. J Prosthet Dent. 1997;78:146-152.

9. Eliaz N, Nissan O. Innovative processes for electropolishing of medical devices made of stainless steels. J Biomed Mater Res. 2007;83A:546-557.

10. Hassan L, Juszczyk AS, Clark RK. Immediate replacement removable partial dentures with cobalt-chromium frameworks: Rationale, technology and a case report. J Oral Rehab. 2005;32:772-775.

11. Knezović-Zlatarić D, Nemet M, Baućić I. Laboratory fabrication procedures of a metal partial denture framework. Acta Stomat Croat. 2003;37:95-98.

12. Kuhar M, Funduk N. Effects of polishing techniques on the surface roughness of acrylic denture base resins. J Prosthet Dent. 2005;93:76-85.

13. Bollen CM, Papaioannou W, Van Eldere J, Schepers E, Quirynen M, van Steenberghe D. The influence of abutment surface roughness on plaque accumulation and peri-implant mucositis. Clin Oral Implants Res. 1996;7:201-211.

14. Ţălu Ş, Stach S, Klaić B, Mišić T, Malina J, Čelebić A. Morphology of Co-Cr-Mo dental alloy surfaces polished by three different mechanical procedures. Microsc Res Tech. 2015;78:831-839.

15. Hensel KB. Electropolishing. Met Finish. 2000;98:440-448.

16. Jumer JF. Electropolishing. Met Finish. 1995:93;420-427.

17. Wataha JC, Lockwood PE, Khajotia SS, Turner R. Effect of $\mathrm{pH}$ on element release from dental casting alloys. J Prosthet Dent. 1998;80:691-698.

18. Carreiro AFP, Ribeiro RF, de Mattos MGC, et al. Evaluation of the castability of a Co-Cr-Mo-W alloy varying the investing technique. Braz Dent J. 2005;16:50-55.

19. Gupta KP. The Co-Cr-Mo (cobalt-chromium-molybdenum) system. J Phase Equilib Diff. 2005;26:87-92.

20. Silva JW, Sousa LL, Nakazato RZ, Codaro EN, de Felipe H. Electrochemical and microstructural study of $\mathrm{Ni}-\mathrm{Cr}$-Mo alloys used in dental prostheses. Mater Sci Applicat. 2011;2:42-48.

21. Örtorp A, Jönsson D, Mouhsen A, Vult von Steyern P. The fit of cobalt-chromium three-unit fixed dental prostheses fabricated with four different techniques: A comparative in vitro study. Dent Mater. 2011;27:356-363.

22. Taylor R, Maryan C, Verran J. Retention of oral microorganisms on cobalt-chromium alloy and dental acrylic resin with different surface finishes. J Prosthet Dent. 1998;80:592-597.

23. Aydin AK. Evaluation of finishing and polishing techniques on surface roughness of chromium-cobalt castings. J Prosthet Dent. 1991;65:763-767.

24. Bezzon OL, Pedrazzi H, Zaniquelli O, da Silva TB. Effect of casting technique on surface roughness and consequent mass loss after polishing of $\mathrm{NiCr}$ and $\mathrm{CoCr}$ base metal alloys: A comparative study with titanium. J Prosthet Dent. 2004;92:274-277.

25. Felipucci DN, Davi LR, Paranhos HF, Bezzon OL, Silva RF, Pagnano VO. Effect of different cleansers on the surface of removable partial denture. Braz Dent J. 2011;22:392-397. 